\title{
PENGARUH PEMBERIAN DOSIS PUPUK NPK DAN PUPUK PELENGKAP TERHADAP PERTUMBUHAN DAN PRODUKSI TANAMAN SEDAP MALAM
}

\author{
(Polianthes tuberosa L.)
}

\author{
Tiara Anggun Puspita, Kus Hendarto, Tri Dewi Andalasari \& Setyo Widagdo \\ Jurusan Agroteknologi Fakultas Pertanian Universitas Lampung \\ Jl. Sumantri Brojonegoro No 1 Bandar Lampung
}

\begin{abstract}
ABSTRAK
Sedap malam merupakan salah satu tanaman hias yang banyak disukai masyarakat. Bunga sedap malam tergolong bunga potong yang laku di pasaran setelah mawar dan krisan. Untuk meningkatkan produksi bunga sedap malam yaitu dengan memperbaiki pertumbuhan dan kualitas bunga. Perbaikan kualitas bunga sedap malam dapat dilakukan dengan pemberian unsur hara yang cukup dan seimbang. Penelitian ini bertujuan untuk mengetahui pengaruh pemberian dosis pupuk NPK dan pupuk pelengkap Plant Catalyst terhadap pertumbuhan dan produksi tanaman sedap malam. Penelitian ini menggunakan Rancangan Acak Kelompok (RAK) yang disusun secara faktorial $(4 \times 4)$ dengan setiap satuan percobaan digandakan yaitu pupuk NPK Mutiara (16-16-16) (N) yaitu $\mathrm{N}_{0}(0), \mathrm{N}_{1}(10 \mathrm{~g} /$ tanaman $), \mathrm{N}_{2}(15 \mathrm{~g} / \mathrm{tanaman}), \mathrm{N}_{3}(20 \mathrm{~g} / \mathrm{tanaman})$. Faktor kedua adalah konsentrasi pupuk pelengkap Plant Catalyst $(\mathrm{P})$ yaitu $\mathrm{P}_{0}(0), \mathrm{P}_{1}(1 \mathrm{~g} / \mathrm{l}), \mathrm{P}_{2}(1,5 \mathrm{~g} / \mathrm{l}), \mathrm{P}_{3}(2 \mathrm{~g} / \mathrm{l})$. Hasil penelitian menunjukkan bahwa pemberian dosis pupuk NPK dan pupuk Pelengkap Plant Catalyst tidak memberikan pengaruh yang berbeda nyata pada variabel pengamatan vegetatif tanaman sedap malam. Pemberian pupuk NPK dengan dosis $20 \mathrm{~g} / \mathrm{tanaman}$ memberikan hasil yang terbaik pada variabel pengamatan panjang rangkaian bunga, panjang bunga keseluruhan, diameter tangkai bunga, diameter bunga, dan jumlah kuntum. Pemberian pupuk pelengkap Plant Catalyst $1,5 \mathrm{~g} / \mathrm{l} \mathrm{memberikan} \mathrm{hasil} \mathrm{yang} \mathrm{terbaik} \mathrm{pada}$ variabel pengamatan panjang bunga keseluruhan, diameter tangkai bunga, diameter bunga, dan jumlah kuntum.
\end{abstract}

Kata kunci : plant catalyst, produksi tanaman, pupuk NPK, sedap malam.

\section{PENDAHULUAN}

Sedap malam (Polianthes tuberosa L.) merupakan salah satu tanaman hias yang banyak disukai masyarakat. Bunga ini mempunyai aroma yang harum juga khas bila dibandingkan dengan tanaman bunga yang lain. Bunga potong sedap malam tidak saja dijumpai di rumah-rumah, tetapi juga di gedung-gedung pertemuan, hotel-hotel berbintang bahkan rumah sakit. Sedap malam selain digunakan sebagai bunga potong, juga banyak dimanfaatkan sebagai bunga tabur dan bahan baku industri minyak atsiri yang berpotensi untuk dikembangkan.

Produktivitas tanaman sedap malam di Lampung mencapai 7 ton/ha pada tahun 2012, tahun 2013 produktivitasnya 6 ton/ha sedangkan pada tahun 2014 produktivitas tanaman sedap malam mengalami penurunan hingga dua kali yaitu 3 ton/ha. Rendahnya produktivitas sedap malam dapat dipengaruhi oleh beberapa faktor yakni, masalah kesuburan tanah, cara pemupukan, bibit, cara bercocok tanam, jasad pengganggu dan sebagainya (Direktorat Jenderal Hortikultura, 2014). Rendahnya pembungaan dan kualitas bunga sedap malam merupakan salah satu permasalahan yang sering timbul pada pembudidayaan sedap malam. Aspek yang paling penting dalam pemasaran bunga adalah kualitas bunga. Syarat pokok yang harus dipenuhi agar bunga dapat diterima oleh masyarakat adalah bunga dengan diameter tangkai bunga yang besar, bunga yang tidak mudah rontok, warna bunga yang cerah, serta ketahanan bunga yang lama (Direktorat Jenderal Hortikultura, 2014). Untuk menghasilkan hasil yang terbaik dari tanaman maka pupuk yang diberikan harus dalam jumlah yang tepat sehingga semua unsur yang dibutuhkan tanaman dapat terpenuhi.

Tujuan penelitian ini adalah untuk mengetahui pengaruh pemberian dosis pupuk NPK dan pupuk plant catalyst terhadap pertumbuhan dan produksi tanaman sedap malam

\section{BAHAN DAN METODE}

Penelitian ini dilaksanakan di Gg. Swadaya 6 Kelurahan Gunung Terang pada bulan Januari-Juni 2016. Bahan tanam yang digunakan pada penelitian ini berupa 
umbi tanaman sedap malam dengan diameter umbi 2$4,65 \mathrm{~cm}$ yang didapatkan dari petani lokal desa Wonotirto, Tanggamus. Rancangan pada penelitian ini menggunakan Rancangan Acak Kelompok (RAK) yang disusun secara faktorial $(4 \times 4)$ dengan faktor pertama adalah konsentrasi pupuk NPK Mutiara $(\mathrm{N})$ dengan empat taraf dosis yaitu, $\mathrm{n}_{0}(0), \mathrm{n}_{1}(10 \mathrm{~g} / \mathrm{tanaman}), \mathrm{n}_{2}(15 \mathrm{~g} /$ tanaman), $\mathrm{n}_{3}(20 \mathrm{~g} /$ tanaman). Faktor kedua adalah pupuk pelengkap $(\mathrm{P})$ dengan empat taraf dosis yaitu, $\mathrm{p}_{0}(0), \mathrm{p}_{1}$ $(1 \mathrm{~g} / \mathrm{l}), \mathrm{p}_{1.5}(1,5 \mathrm{~g} / \mathrm{l}), \mathrm{p}_{2}(2 \mathrm{~g} / \mathrm{l})$. Satuan percobaan berjumlah 16 perlakuan yang diulang sebanyak 3 kali dan setiap perlakuan digandakan. Homogenitas ragam diuji dengan uji-bartlet dengan taraf nyata 5\% dan uji tukey. Jika asumsi terpenuhi, maka dilakukan analisis ragam (uji F) Jika nilai uji $\mathrm{F}$ nyata maka dilakukan pemisahan nilai tengah dengan menggunakan uji BNJ $5 \%$.

Pemupukan NPK (16:16:16) dilakukan pada saat tanaman berumur satu bulan setelah tanam dan diberikan setiap satu bulan sekali sampai tanaman berumur tiga bulan setelah tanam. Aplikasi pupuk pelengkap plant catalyst dilakukan dengan cara disiramkan pada media tanaman sesuai dengan konsentrasinya dan volumenya yaitu $250 \mathrm{ml} /$ tanaman yang dilakukan pada saat tanaman berumur satu bulan setelah tanam dan diberikan setiap satu bulan sekali sampai tanaman berumur enam bulan setelah tanam. Pengamatan dilakukan pada saat tanaman berumur dua bulan setelah tanam, variabel pengamatan yang diamati pada penelitian ini meliputi panjang daun, jumlah daun, lebar daun, waktu muncul kuncup bunga, waktu mekar bunga, panjang tangkai bunga, panjang rangkaian bunga, panjang bunga keseluruhan, diameter tangkai, diameter bunga, jumlah kuntum, dan jumlah anakan.

\section{HASIL DAN PEMBAHASAN}

Hasil penelitian menunjukkan bahwa perlakuan dosis pupuk NPK dan pupuk pelengkap tidak berpengaruh nyata pada pertumbuhan vegetatif tanaman yaitu pada variabel panjang daun, jumlah daun, lebar daun, dan jumlah anakan. Pengaruh pemberian pupuk
NPK terhadap pertumbuhan dan produksi sedap malam tidak bergantung pada pemberian pupuk pelengkap pada variabel pengamatan vegetatif tanaman (Tabel 1). Hasil penelitian pada variabel fase generatif yakni, waktu muncul kuncup bunga, waktu mekar bunga, panjang tangkai bunga, panjang rangkaian bunga, diameter tangkai bunga, diameter bunga, panjang bunga keseluruhan, dan jumlah kuntum dilakukan perbandingan nilai rata-rata antara setiap perlakuan dan tidak dilakukan analisis ragam.

Hasil penelitian menunjukkan bahwa perlakuan pupuk NPK dan pupuk pelengkap tidak berpengaruh terhadap panjang daun, jumlah daun, dan lebar daun. Pengaruh pemberian pupuk NPK terhadap pertumbuhan sedap malam tidak bergantung pada pemberian pupuk pelengkap. Pemberian pupuk NPK $10 \mathrm{~g} / \mathrm{tan}$ dan pupuk pelengkap $1,5 \mathrm{~g} / \mathrm{l}$ pada umur 5 bulan $\left(\mathrm{n}_{1} \mathrm{p}_{2}\right)$ menunjukkan nilai rata-rata panjang daun tertinggi yaitu $66,4 \mathrm{~cm}$, Pemberian pupuk NPK $10 \mathrm{~g} / \mathrm{tan}$ dan pupuk pelengkap $1 \mathrm{~g} / \mathrm{l}\left(\mathrm{n}_{1} \mathrm{p}_{1}\right)$ menunjukkan nilai rata-rata panjang daun terendah yaitu 57,4 cm (Gambar 1a), $\mathrm{n}_{2} \mathrm{p}_{2}$ menghasilkan nilai rata-rata jumlah daun yaitu 96,5 helai daun, $\mathrm{n}_{0} \mathrm{p}_{2}$ menghasilkan nilai rata-rata jumlah daun yaitu 63,3 helai daun (Gambar 1b), $n_{1} p_{3}$ menghasilkan nilai rata-rata lebar daun yaitu $2,1 \mathrm{~cm}, \mathrm{n}_{2} \mathrm{p}_{3}$ menghasilkan nilai ratarata lebar daun yaitu $2,1 \mathrm{~cm}$ (Gambar 2a).

Hasil penelitian menunjukkan bahwa secara kuantitatif, waktu muncul kuncup bunga lebih cepat pada pemberian pupuk NPK $10 \mathrm{~g} / \operatorname{tanaman}(\mathrm{N} 1)$ yaitu 143 hari, pemberian pupuk NPK 0 g/tanaman (N0) lebih lama yaitu 172 hari. Pemberian pupuk pelengkap $1 \mathrm{~g} / \mathrm{l}$ (P1) waktu muncul kuncup bunga lebih cepat yaitu 128 hari, pemberian pupuk pelengkap 0 (P0) lebih lama yaitu 220 hari (Gambar 2b). Hasil penelitian menunjukkan bahwa waktu mekar bunga lebih cepat pada pemberian pupuk NPK $20 \mathrm{~g} / \operatorname{tanaman}(\mathrm{N} 3)$ yaitu 17 hari, pemberian pupuk NPK $0 \mathrm{~g} / \operatorname{tanaman}(\mathrm{N} 0)$ yaitu 25 hari. Pemberian pupuk pelengkap $2 \mathrm{~g} / \mathrm{l}(\mathrm{P} 3)$ waktu mekar bunga lebih cepat yaitu 16 hari yang menunjukkan waktu lebih cepat mekar bunga sedap malam , tanpa pemberian pupuk pelengkap (P0) yaitu 22 hari (Gambar 3a).

Tabel 1. Rekapitulasi analisis ragam pengaruh pemberian pupuk NPK dan pupuk pelengkap untuk semua variabel pengamatan pertumbuhan dan produksi tanaman sedap malam.

\begin{tabular}{ccccc}
\hline No & $\begin{array}{c}\text { Variabel } \\
\text { Pengamatan }\end{array}$ & $\begin{array}{c}\text { NPK } \\
(\text { NPK })\end{array}$ & $\begin{array}{c}\text { Pupuk Pelengkap } \\
(\text { PP })\end{array}$ & $\begin{array}{c}\text { Pengaruh Interaksi } \\
\text { NxP }\end{array}$ \\
\hline 1 & Panjang daun & tn & tn & tn \\
2 & Jumlah daun & tn & tn & tn \\
3 & Lebar daun & tn & tn & tn \\
4 & Jumlah anakan & tn & tn & tn \\
\hline
\end{tabular}

Keterangan : tn : tidak nyata pada BNJ $\alpha=5 \%$ 


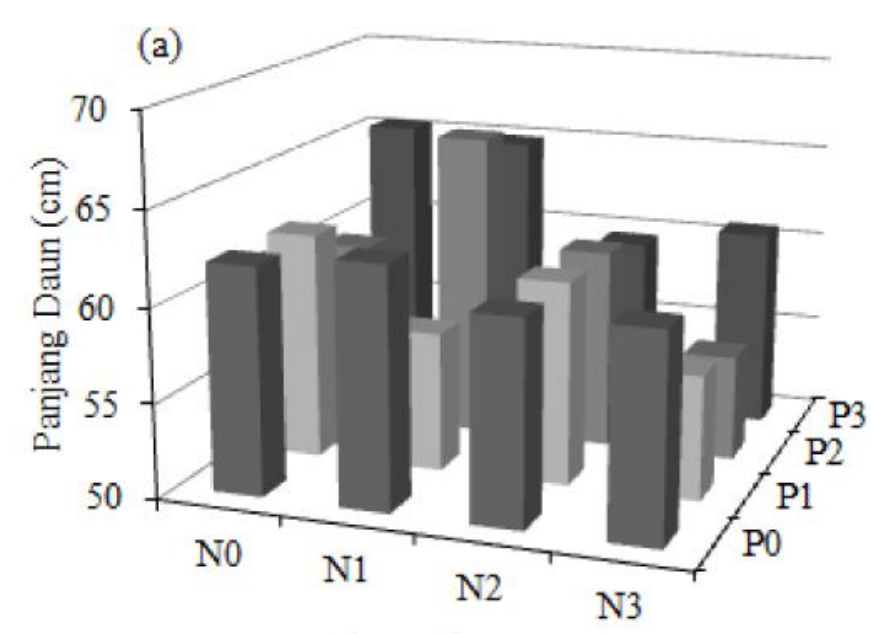

Dosis pupuk NPK

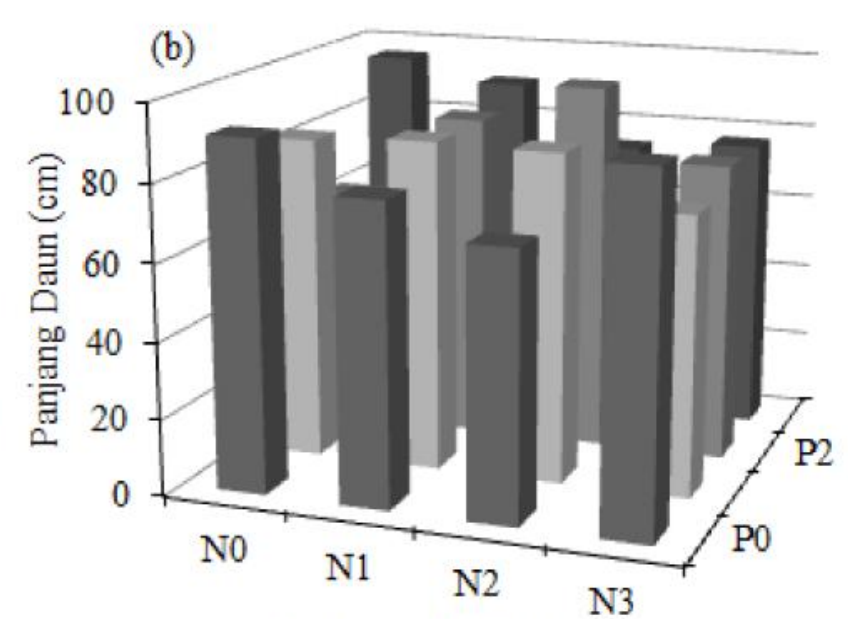

Dosis pupuk NPK

Gambar 1. Pengaruh pemberian pupuk NPK dan pupuk pelengkap terhadap (a) panjang daun (b) jumlah daun pada tanaman sedap malam umur 5 bulan. Keterangan: N0 = Tanpa NPK, N1 = NPK $10 \mathrm{~g} / \operatorname{tanaman}, \mathrm{N} 2=$ NPK 15 g/tanaman, N3 = NPK 20 g/tanaman, P0 = Tanpa Pupuk Pelengkap (PP), P1 = PP 1 g/l, P2 $=$ PP $1,5 \mathrm{~g} / \mathrm{l}, \mathrm{P} 3=\mathrm{PP} 2 \mathrm{~g} / \mathrm{l}$.

(a)

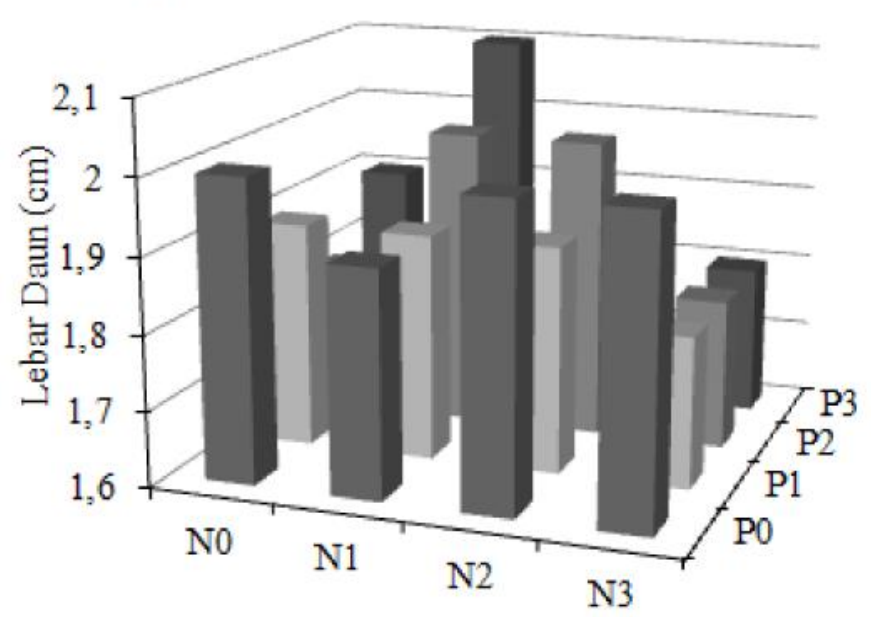

Dosis pupuk NPK (b)

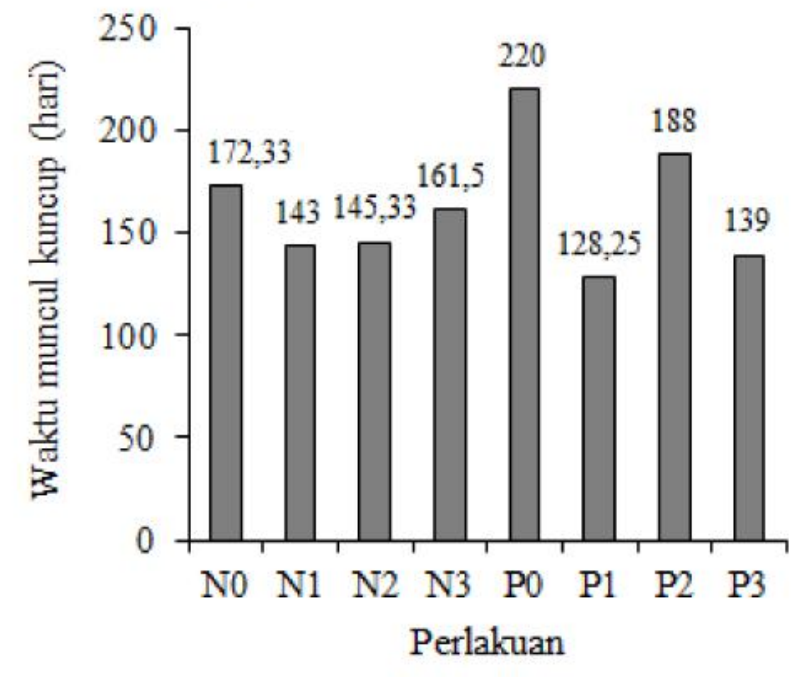

Gambar 2. Pengaruh pemberian pupuk NPK dan pupuk pelengkap terhadap (a) lebar daun umur 5 bulan (b) waktu muncul kuncup bunga pada tanaman sedap malam. Keterangan: N0 = Tanpa NPK, N1 = NPK $10 \mathrm{~g} /$ tanaman, N2 = NPK $15 \mathrm{~g} /$ tanaman, N3 = NPK $20 \mathrm{~g} /$ tanaman, P0 = Tanpa Pupuk Pelengkap (PP), P1 $=\mathrm{PP} 1 \mathrm{~g} / \mathrm{l}, \mathrm{P} 2=\mathrm{PP} 1,5 \mathrm{~g} / \mathrm{l}, \mathrm{P} 3=\mathrm{PP} 2 \mathrm{~g} / \mathrm{l}$.

Hasil penelitian menunjukkan bahwa panjang tangkai bunga pada pemberian pupuk NPK $15 \mathrm{~g} / \mathrm{tanaman}$ (N2) dan pupuk pelengkap $2 \mathrm{~g} / \mathrm{l}(\mathrm{P} 3)$ yaitu $60,67 \mathrm{~cm}$, dan $60,25 \mathrm{~cm}$, dan pemberian pupuk NPK $0 \mathrm{~g} / \mathrm{tan}$ dan pupuk pelengkap $1,5 \mathrm{~g} / \mathrm{l}(\mathrm{P} 2)$ memiliki nilai rata-rata terendah yaitu $51,17 \mathrm{~cm}$ dan $28,50 \mathrm{~cm}$ (Gambar $3 b$ ). Hasil penelitian menunjukkan bahwa panjang rangkaian bunga pemberian pupuk NPK $20 \mathrm{~g} / \operatorname{tanaman}$ (N3) dan pupuk pelengkap $2 \mathrm{~g} / \mathrm{l}(\mathrm{P} 3)$ yaitu $28,50 \mathrm{~cm}$, dan 26,38 $\mathrm{cm}$, dan pemberian pupuk NPK $10 \mathrm{~g} / \tan (\mathrm{N} 1)$ dan pupuk pelengkap 1,5 g/l (P2) memiliki nilai rata-rata terendah yaitu $23 \mathrm{~cm}$ dan 15,50 $\mathrm{cm}$ (Gambar 4a). Hasil penelitian menunjukkan bahwa panjang bunga keseluruhan pada pemberian pupuk NPK $20 \mathrm{~g} /$ tanaman (N3) dan pupuk pelengkap 1,5 g/l (P2) yaitu $87,25 \mathrm{~cm}$, dan $88 \mathrm{~cm}$, dan pemberian pupuk NPK $0 \mathrm{~g} / \tan$ (N0) dan tanpa pupuk pelengkap (P0) memiliki nilai rata-rata terendah yaitu $74,17 \mathrm{~cm}$ dan $72 \mathrm{~cm}$ (Gambar 4b). 
(a)

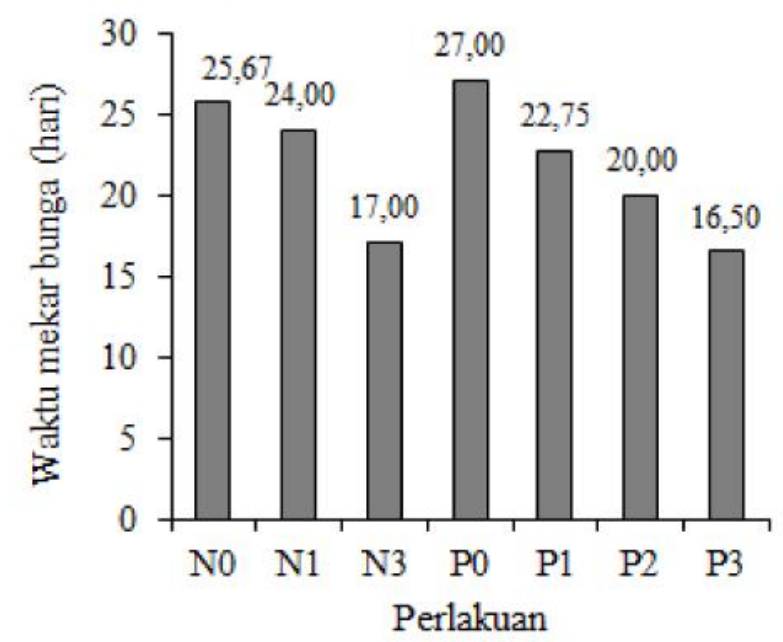

(b)

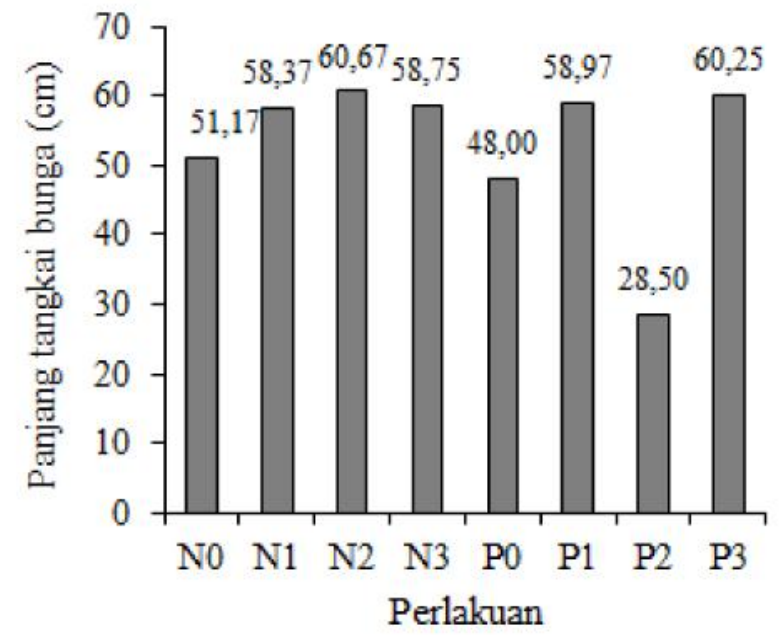

Gambar 3. Pengaruh pemberian pupuk NPK dan pupuk pelengkap terhadap (a) waktu mekar bunga (b) panjang tangkai bunga pada tanaman sedap malam. Keterangan: N0 = Tanpa NPK, N1 = NPK $10 \mathrm{~g} /$ tanaman, N2 = NPK 15 g/tanaman, N3 = NPK 20 g/tanaman, P0 = Tanpa Pupuk Pelengkap (PP), P1 = PP 1 $\mathrm{g} / \mathrm{l}, \mathrm{P} 2=\mathrm{PP} 1,5 \mathrm{~g} / \mathrm{l}, \mathrm{P} 3=\mathrm{PP} 2 \mathrm{~g} / \mathrm{l}$.

(a)

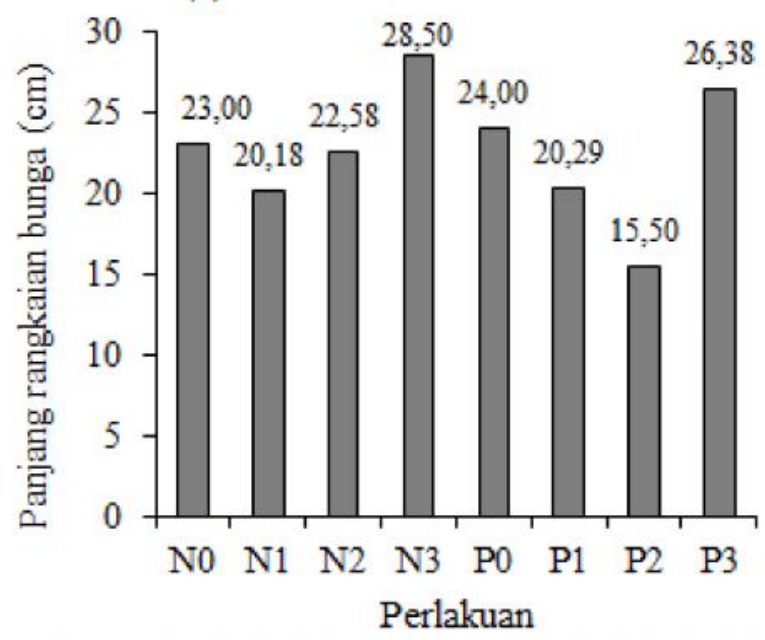

(b)

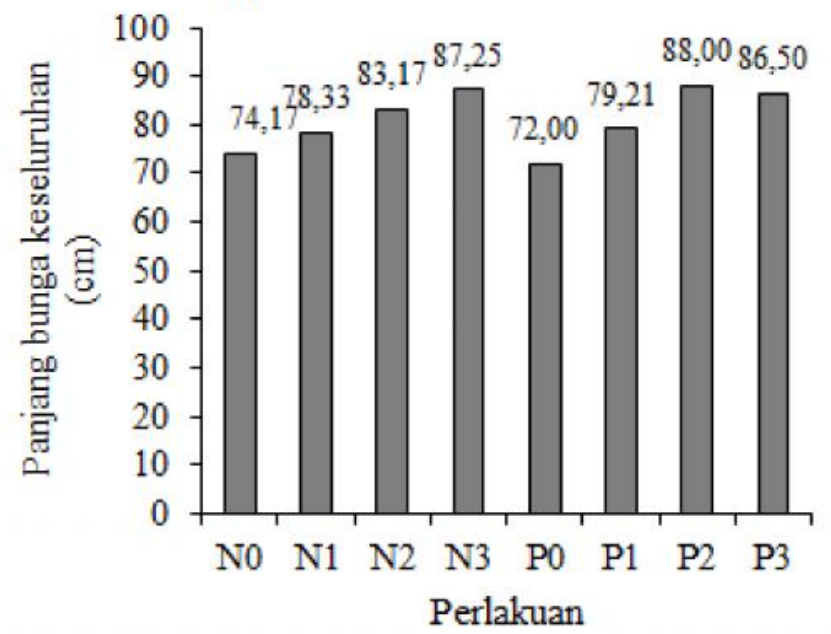

Gambar 4. Pengaruh pemberian pupuk NPK dan pupuk pelengkap terhadap (a) panjang rangkaian bunga (b) panjang bunga keseluruhan pada tanaman sedap malam. Keterangan: N0 = Tanpa NPK, N1 = NPK 10 g/tanaman, N2 = NPK 15 g/tanaman, N3 = NPK 20 g/tanaman, P0 = Tanpa Pupuk Pelengkap (PP), $\mathrm{P} 1=\mathrm{PP} 1 \mathrm{~g} / \mathrm{l}, \mathrm{P} 2$ = PP $1,5 \mathrm{~g} / \mathrm{l}, \mathrm{P} 3=\mathrm{PP} 2 \mathrm{~g} / \mathrm{l}$.

Hasil penelitian menunjukkan bahwa diameter tangkai bunga pada pemberian pupuk NPK $20 \mathrm{~g} / \operatorname{tanaman}$ (N3) yaitu $1,08 \mathrm{~cm}$ dan pemberian pupuk pelengkap menunjukkan nilai yang relatif sama pada semua perlakuan, dan pemberian pupuk NPK $0 \mathrm{~g} / \tan (\mathrm{N} 0)$ memiliki nilai rata-rata terendah yaitu 74,17 (Gambar 5a). Hasil penelitian menunjukkan bahwa diameter bunga pada pemberian pupuk NPK $20 \mathrm{~g} / \operatorname{tanaman}(\mathrm{N} 3)$ dan pemberian pupuk pelengkap $1,5 \mathrm{~g} / \mathrm{l}(\mathrm{P} 2)$ yaitu 2,20 $\mathrm{cm}$, dan 2,30 $\mathrm{cm}$, dan pemberian pupuk NPK $0 \mathrm{~g} /$ tanaman (N0) dan tanpa pupuk pelengkap (P0) memiliki nilai rata-rata terendah yaitu $1,17 \mathrm{~cm}$ dan $1,1 \mathrm{~cm}$ (Gambar 5b). Hasil penelitian menunjukkan bahwa jumlah kuntum pada pemberian pupuk NPK 20 g/tanaman (N3) dan pemberian pupuk pelengkap 1,5 g/l (P2) yaitu 35,50 kuntum, dan 39 kuntum, pemberian pupuk NPK $15 \mathrm{~g} / \tan (\mathrm{N} 2)$ dan pupuk pelengkap $1 \mathrm{~g} / \mathrm{l}$ (P1) memiliki nilai rata-rata terendah yaitu 29 kuntum 
cm dan 24,88 kuntum (Gambar 6a). Hasil penelitian pada jumlah anakan menunjukkan pemberian pupuk NPK dan pupuk pelengkap tidak berpengaruh terhadap jumlah anakan. Pengaruh pemberian pupuk NPK terhadap pertumbuhan sedap malam tidak bergantung pada pemberian pupuk pelengkap begitu juga interaksi keduanya tidak berpengaruh. Pemberian pupuk NPK $10 \mathrm{~g} /$ tanaman dan pupuk pelengkap $2 \mathrm{~g} / \mathrm{l}$ pada umur 5 bulan $\left(n_{1} p_{3}\right)$ menunjukkan nilai jumlah anakan yang lebih banyak yaitu 3,8 anakan, dan pemberian pupuk NPK $10 \mathrm{~g} /$ tanaman dan pupuk pelengkap $1 \mathrm{~g} / \mathrm{l}\left(\mathrm{n}_{1} \mathrm{p}_{1}\right)$ menunjukkan nilai rata-rata panjang daun terendah yaitu 2,8 anakan (Gambar 6b).

Pembahasan. Hasil penelitian menunjukkan bahwa pemberian pupuk NPK dan pupuk pelengkap tidak memberikan pengaruh yang nyata pada variabel panjang daun, jumlah daun, lebar daun, dan jumlah anakan. Pemberian pupuk NPK tidak dipengaruhi oleh (a)

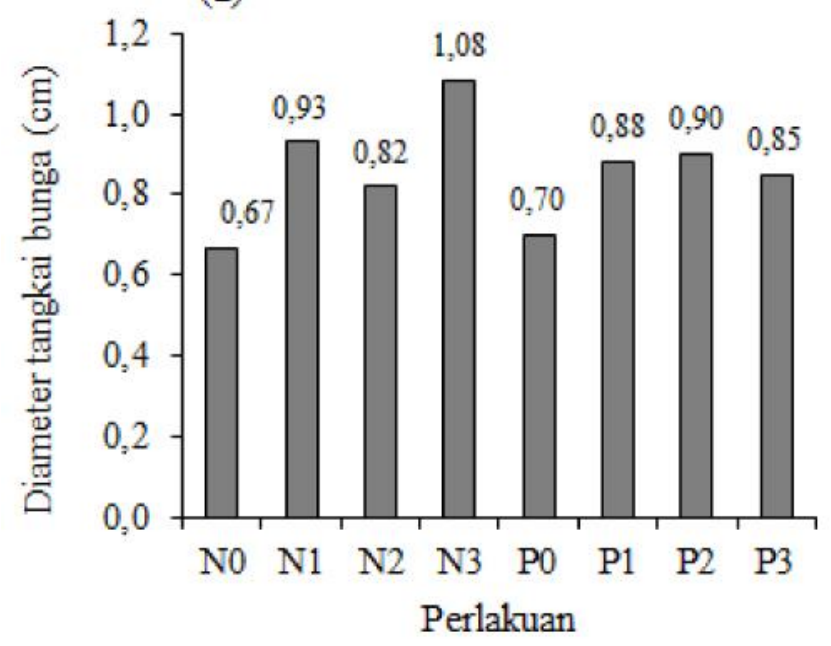

(b)

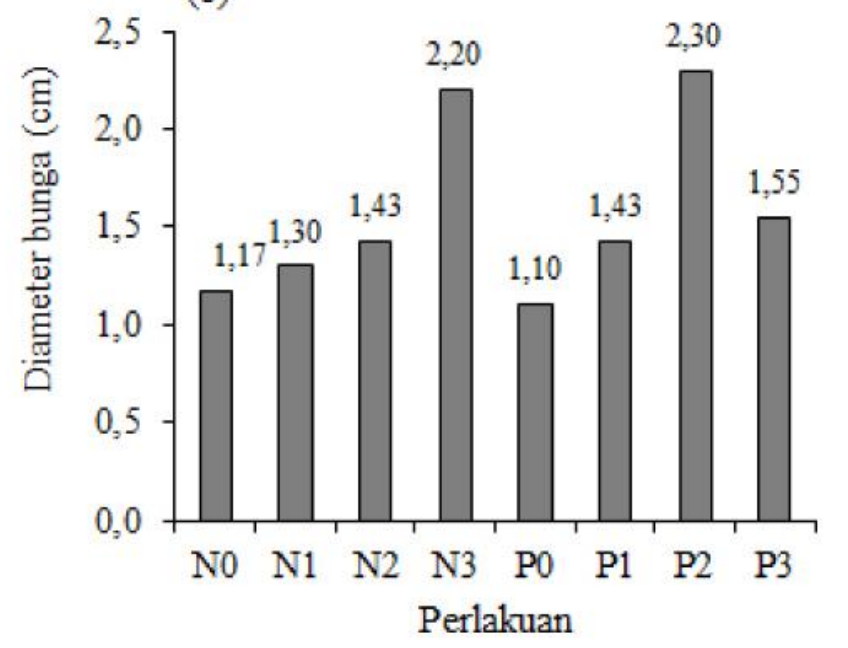

Gambar 5. Pengaruh pemberian pupuk NPK dan pupuk pelengkap terhadap (a) diameter tangkai bunga (b) diameter bunga pada tanaman sedap malam. Keterangan: N0 = Tanpa NPK, N1 = NPK 10 g/tanaman, N2 = NPK 15 g/tanaman, N3 = NPK 20 g/tanaman, P0 = Tanpa Pupuk Pelengkap (PP), P1 = PP 1 g/l, P2 $=$ PP $1,5 \mathrm{~g} / 1, \mathrm{P} 3=\mathrm{PP} 2 \mathrm{~g} / \mathrm{l}$.

(a)

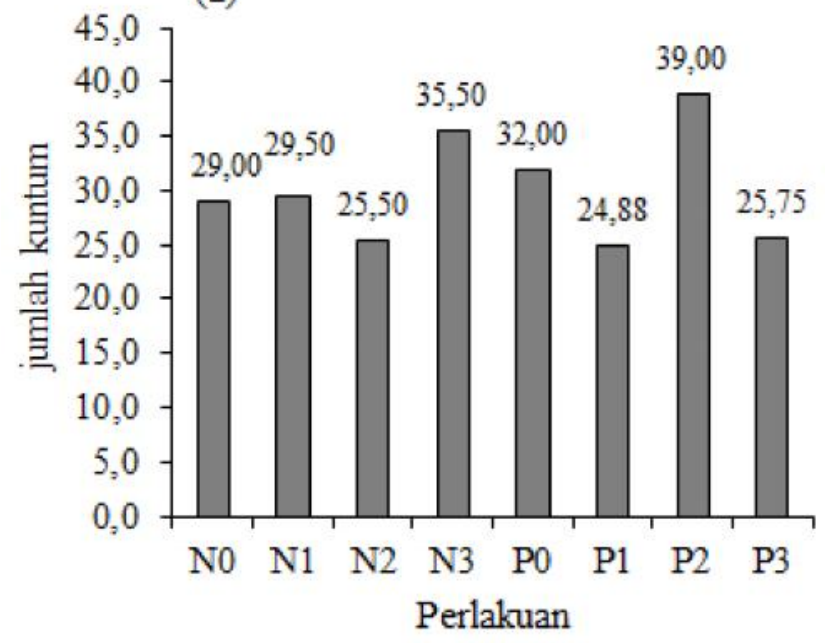

(b)

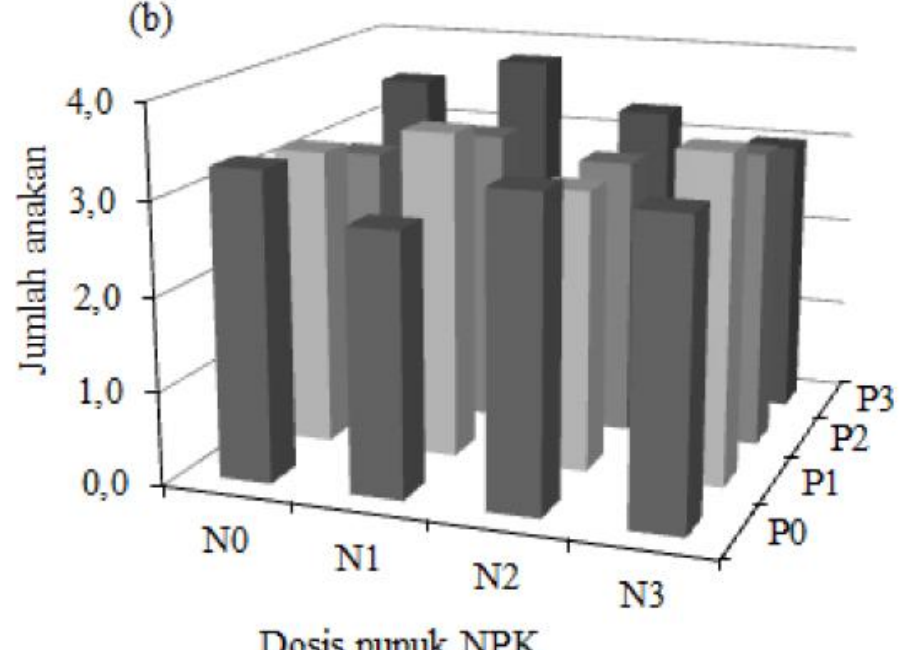

Gambar 6. Pengaruh pemberian pupuk NPK dan pupuk pelengkap terhadap (a) waktu mekar bunga (b) panjang tangkai bunga umur 5 bulan pada tanaman sedap malam. Keterangan: N0 $=$ Tanpa NPK, N1 $=$ NPK $10 \mathrm{~g} /$ tanaman, N2 = NPK $15 \mathrm{~g} /$ tanaman, N3 = NPK $20 \mathrm{~g} / \operatorname{tanaman}, \mathrm{P} 0=$ Tanpa Pupuk Pelengkap (PP), $\mathrm{P} 1=\mathrm{PP} 1 \mathrm{~g} / \mathrm{l}, \mathrm{P} 2$ = PP 1,5 g/l, P3 = PP $2 \mathrm{~g} / \mathrm{l}$. 
pemberian pupuk pelengkap demikian pula sebaliknya. Pada fase vegetatif tanaman sedap malam, variabel pengamatan panjang daun, jumlah daun, dan lebar daun pemberian pupuk NPK 0, 10, 15, dan $20 \mathrm{~g} / \mathrm{tanaman}$ tidak menunjukkan pengaruh yang berbeda.

Hal itu diduga karena unsur hara yang diperlukan telah tercukupi dari kandungan media untuk mendukung pertumbuhan tanaman sedap malam yang terdiri tanah, pupuk kandang kambing serta sekam padi. Sejalan dengan hasil peneltian Sulistyaningsih (2007) bahwa pemberian kombinasi media tanam tanah + pupuk kandang + sekam padi pada tanaman sedap malam memberikan hasil yang terbaik pada variabel panjang daun, jumlah daun dibandingkan dengan kombinasi media tanah + pupuk kandang + serutan kayu.

Media tanam yang digunakan pada penelitian ini campuran dari tanah: pupuk kandang: sekam padi, yaitu 1:1:1. Pada penelitian ini bobot media tanam seberat 5 $\mathrm{kg}$, dengan bobot media tersebut diduga jumlah unsur hara $\mathrm{N}$ yang terkandung dalam media yang digunakan cukup tinggi. Maka penambahan unsur $\mathrm{N}$ melalui pemupukan menjadi tidak berpengaruh.

Hasil penelitian menunjukkan bahwa pada variabel waktu muncul kuncup bunga, waktu mekar bunga, panjang tangkai bunga, panjang rangkaian bunga, panjang bunga keseluruhan, diameter tangkai, diameter bunga dan jumlah kuntum memberikan hasil terbaik pada pemberian pupuk NPK kisaran 15- $20 \mathrm{~g} /$ tanaman dibandingkan perlakuan lain. Hal ini selaras dengan hasil penelitian Sari (2009) bahwa pemberian pupuk NPK 15 $\mathrm{g} /$ tanaman mampu mempercepat waktu muncul kuncup bunga, waktu mekar bunga, panjang rangkaian bunga, panjang bunga keseluruhan, dan diameter tangkai bunga.

Pemberian pupuk pelengkap Plant Catalyst dengan konsentrasi 1,5 g/l (P3) secara umum memberikan hasil terbaik pada pertumbuhan generatif tanaman dibandingkan perlakuan lain. Pada penelitian terlihat bahwa pemupukan plant catalyst dengan konsentrasi tersebut menghasilkan jumlah kuntum dengan rata-rata hasil 39 kuntum dan diameter bunga dengan rata-rata hasil $2,30 \mathrm{~cm}$ lebih besar sehingga standard bunga menjadi lebih baik.

Hukum Liebig menyatakan bahwa laju pertumbuhan diatur oleh adanya faktor yang berada dalam jumlah minimum dan besar kecilnya laju pertumbuhan ditentukan oleh peningkatkan dan penurunan faktor yang berada dalam jumlah minimum tersebut (Karim, 2009). Hal ini menegaskan bahwa harus ada keseimbangan jumlah unsur hara yang diserap oleh tanaman untuk pertumbuhan dan perkembangan secara optimal. Tanaman akan tumbuh baik bila semua unsur hara yang dibutuhkan oleh tanaman tersedia dalam jumlah yang cukup dan berimbang.

Hasil Penelitian menunjukkan bahwa tidak ada interaksi dari pemberian pupuk NPK dan pemberian pupuk pelengkap pada semua variabel yang diamati. Berdasarkan penelitian yang telah dilakukan menunjukkan bahwa tanaman sedap malam dapat hidup dengan baik pada berbagai dosis NPK $0 \mathrm{~g} / \mathrm{tan}, 10 \mathrm{~g} / \mathrm{tan}$, $15 \mathrm{~g} / \mathrm{tan}$, dan $20 \mathrm{~g} / \mathrm{tan}$ dengan pemberian pupuk pelengkap plant catalyst $0 \mathrm{~g} / \mathrm{l}, 1 \mathrm{~g} / \mathrm{l}, 1,5 \mathrm{~g} / \mathrm{l}$, dan $2 \mathrm{~g} / \mathrm{l}$, namun demikian jika dilihat rata-rata panjang rangkaian, panjang bunga keseluruhan, diameter tangkai bunga, diameter bunga, dan jumlah kuntum yang paling baik adalah dengan menggunakan pupuk NPK $20 \mathrm{~g} /$ tanaman dan dengan pemberian pupuk pelengkap plant catalyst $1,5 \mathrm{~g} / 1$.

\section{KESIMPULAN}

Berdasarkan penelitian yang telah dilakukan, maka didapatkan beberapa kesimpulan yaitu hasil penelitian tidak memberikan nilai yang berbeda nyata terhadap seluruh variabel pengamatan pada fase vegetatif. Pemberian perlakuan dosis pupuk NPK $20 \mathrm{~g} /$ tanaman memberikan hasil pada variabel panjang rangkaian bunga dengan nilai rata-rata $28,5 \mathrm{~cm}$, panjang bunga keseluruhan $87,25 \mathrm{~cm}$, diameter tangkai bunga $1,08 \mathrm{~cm}$, diameter bunga $2,20 \mathrm{~cm}$, dan 35,5 jumlah kuntum.Perlakuan pemberian pupuk pelengkap plant catalyst pada konsentrasi $1,5 \mathrm{~g} / 1$ plant catalyst menghasilkan nilai rata-rata yang lebih tinggi pada variabel panjang bunga keseluruhan $88 \mathrm{~cm}$, diameter tangkai bunga dengan nilai rata-rata $0,9 \mathrm{~cm}$, jumlah kuntum dengan hasil 39 kuntum, dan diameter bunga dengan rata-rata hasil 2,30 $\mathrm{cm}$. Pemberian dosis pupuk NPK tidak dipengaruhi oleh pemberian pupuk pelengkap, demikian juga sebaliknya pemberian pupuk pelengkap tidak dipengaruhi oleh pemberian pupuk NPK.

\section{DAFTAR PUSTAKA}

Badan Pusat Statistik dan Direktorat Jendral Hortikultura. 2014. Statistik Produksi Hortikultura. [10 September 2016].

Karim, M, E. 2009. Analisis Sistem dan Simulasi Peningkatan Produksi Padi Melalui Penggunaan Teknologi Spesifik Lokasi. http:/ www.litbang.pertanian.go.id/special/padi/ bbpadi_2009_itkp_16.pdf. [8 September 2016]. 
Saputri, Wendi. 2012. Pengaruh Dosis Pupuk Majemuk NPK (16:16:16) dan Pupuk Pelengkap Cair Pada pertumbuhan dan Produksi Tanaman Tomat (Lycopersicum esculentum Mill.) [skripsi]. Lampung. Universitas Lampung. $86 \mathrm{hlm}$.

Sari, D. S. 2009. Pengaruh Dosis NPK dan Jenis Pupuk Daun terhadap Pertumbuhan Dan Produksi Bunga Sedap Malam (Pholianthus tuberosa L.). Universitas Lampung. Lampung. $56 \mathrm{hlm}$.

Sulistyaningsih, L. N. 2007. Pengaruh Campuran Media Tanam Dan Sitokinin Terhadap pertumbuhan Dan Produksi Bunga Sedap Malam (Polianthes tuberosa L.). Agria 4(1): $1-6$. 